\title{
CLASSROOM MANAGEMENT IN THE TEACHING AND LEARNING OF HISTORY
}

\author{
Sri Handayani ${ }^{1}$
}

\begin{abstract}
History education, including the teaching and learning of history, is a form of teaching and learning that is establishing national character values as to develop critical and chronological thinking as well as to acquire knowledge about the past in order to understand and explain the development and the changes in society as well as socio cultural diversity in order to find national identity among world society. The goals of the teaching and learning will be achieved if the student are well managed. As to manage teaching and learning in a proper way, educational management is required. Teaching and classroom management are a certain activities or process in managing cooperative group efforts in educational organization as to reach the goals effectively and efficiently. The functions of management includes: planning, organizing, actuating, controlling and evaluating. History education requires the functions in order to manage teaching and learning to be productive. Productivity is reflected from the effectivity and efficiency of learning.
\end{abstract}

Keywords: education management, the teaching and learning of history

\footnotetext{
${ }^{1}$ Sri Handayani, lecture at Study Program of History Education, Department of Social Study at FKIP Universitas Jember. For academic interest, the author can be contacted at home address: Jl. Simpang Karimata Gunung Batu 237 Jember, East Jawa.
} 


\section{Introduction}

Educational field in Indonesia recently encounters a great challenge, i.e. the delay of national examination at senior high school level in eleven provinces. It was not merely about the delay. In several areas, there was also chaos in the practice as in the distribution of the exam sheet, for example the lack of the number of question and answer sheets causing the requirement on duplication. The paper quality of the copied documents did not meet the standard so that they were easily torn down. The massive numbers of news before the National Examination influenced the psychological condition of the students causing them to be weary and dissapointed. The parents were also angry and dissapointend.

The chaos in national examination 2013 dragged all parties, mainly those in the department of education and culture ministry, including teachers and lectures. Everyday, we found abundant unhappy news; educational field in Indonesia was in confusion. One of the factors causing the chaos on the educational practice, mainly in the national examination, was the less optimum implementation of education management.

The practice of national examination which was not conducted appropriately reflects to the coordination, cooperation and communication that did not run well. Coordination, cooperation and communication are the cores of management. Coordination is a very essential part that should not be taken for granted. Without a good coordination, the fund, qualified personnels, as well as facilities, cannot be used optimally, so that the goal of the education is harder to achieve. Cooperation is an activity conducted by the members of an organization so as to eachieve the goals by considering the members' abilities and skills. They help and complete one to another in accordance with their tasks, skills and abilities so that the stated goals of education can be achieved. Communication in educational field, known as educational communication, is the delivery of message or information covering the fields or events in education. Communication is not free anymore, but it is controlled and conditioned towards educational goals. (Naim, 2011; Mulyana, 2010).

History education is the education on historical events as well as the development of society thathadhappenedin thepast time. The main materials in history education refer to the today's products attained from the existing historical resources. The teaching and learning of history is not only about delivering historical facts, but also focusing on the development of abilities or skills in finding or gathering historical trails, analyzing critically towards historical evidence, as well as interpreting and gathering facts, and writing the history in a simple way. History is a school subject focus on knowledge and values pertaining to the changes and development of a society from the past time to the present time (Depdiknas, 2004)

History can educate all humankind to be wise and share various experiences on values in the nation life. Within the teaching and learning, the students are hoped to think critically as well as to use the knowledge about past time to understand the recent and future time. One of the goal of the teaching and learning is goals 
to build a responsible society and to foster the nationalism (Widja, 2002). The goal of the teaching as stated in the standard of competence and basic competence of the history education curriculum.

The history education in the curriculum 2013 that will be effective in the education at year of 2013/2014 was being pushed to the edge. In the curriculum of primary education, the history education belongs to the teach and learn of social science and conducted temathically and holistically. In the curriculum of junior high school level, the teaching and learning of history is conducted in a comprehensive way in accordance with its cluster, namely social science. It is in the curriculum of senior high school level that the history education is conducted independently, based on the field of knowledge.

The history education which basically includes the national character values is more taken for granted by students; since in the primary and junior high school level, it is integrated into the clustered school subjects. The establishment of history education values that should be started in the early education (primary school) is conducted in the senior high school curriculum. History curriculum as well as the teaching and learning are often unable to anticipate the changes in history. This becomes one of worrying things for us as the producer of the generation of history teachers.

Generally, many of the emergent problems in history education include the absent of history lesson in the curriculum of primary and junior high school, where the history education only becomes a part of the clustered lessons. The practice of the teaching and learning, either thematically, integratedly, or independently also shows problems, either in pertaining to the students or the teacher. Several research shows that the history teaching is less interesting to students and it is considered as merely a recalling lesson, the materials are too broad and boring, mainly it is dominated by teachers. It is said that teachers believe that the syllabus only cover a certain topics or problems that are considered to be able to represent a broad range of history. From this, it can be seen that teachers encounter some problems in realizing the acomplishement of the teaching and learning considering the broad range as well as the depth of the materials.

Therefore, the history teachers should understand the education management, especially the teaching management as to manage and to organize the components required in the teaching and learning. So, that it can be effective and efficient. Some serious improvement and development by government or history education practitioners are going to be realized.

\section{Basic Concept of Education Management}

Many experts have proposed some definitions of education management, in line with their fields. Among the experts are: Tony Bush ( 2003), Made Pidarta (1988), Tilaar (2006), Hasbullah (2006), Veithzal Rifai \& Silviana Murni (2008), and Engkoswara \& Aan Komariah (2010). Generally, education management can be defined as an activity or certain activities including the management on the cooperational efforts of a group of humans belong to an educational organization as to reach the educational goals stated before, so that it may run 
effectively and efficiently. In a simple way, education management can be defined as management implemented in educational field with specification and specific character in education (Kurniadin \& Fattah, 2012). The terms of education management in the curriculum 1975 was stated in the "Pedoman Pelaksanaan Kurikulum IIID, baik untuk SD, SMP maupun SMA" (Guidance for the Implementation of the Curriculum IIID, either for Primary, Junior High, and Senior High School Level). The management is all efforts conducted to empower all personnels or material resources effectively and efficiently so as to support the achievement of educational goal (Rohman \& Amri, 2012.) Education management, generally, refers to what are needed to reach the educational goals. Education management refers to the process in pursuing the goal of education. The education process includes planning, organizing, directing, controlling and evaluating (Suryosubroto, 2010).

Planning is an activity on deciding what will be achieved, how long and how to achieve it, how many peoples to be involved, as well as how much is the cost to spend. The planning is composed before it is proceeded. In this activity, besides formulating the goals, it also includes the time limit as well as the steps to be passed as to achieve the goals (Rohman dan Amri, 2012).

Organizing is defined as an activity in setting up some tasks for each persons involved in education. Therefore, since education involves a number of people and a number of tasks to be accomplished. The setting up of the task should be conducted by each organization members. The coordination means that there should be a control so that the task can be conducted according to the stated rules. Each person should know their tasks, than there will be no overlap. In the educational task, time management is a significant issue, what should be in the first list or in the next list. The coordination has a role in integrating the goal of separated activities to reach the goals efficiently and effectively.

Directing is conducted to ensure the activities can be in line with the stated goals to avoid some distortion and inefficiency. All parties involved in education should remember the goals consistently. To ensure that the process is in accordance with the determined goals, there should be some personnels who are good in leadership, i.e. to persuade people to work well as to reach the goals. The directing includes actuating Actuating in an organization is a whole process in motivating employees or students. Actuating has an important position in order to realize a certain goals of organization.

Monitoring or controlling is an activity or efforts to find how far the educational activities have met the goals as well as to find the problems encounterd within the practice. Koonz (1980) states that, "Controlling is the measuring and correcting objective of subordinates to assure that events conform to plans". Monitoring is conducted to discover whether the goals have been achieved or not. Monitoring is aimed at gathering the data on the process of achieving the goals. Monitoring is also used to find the problems encountered during the practice. Monitoring, basically, is data collection towards the practice in educational process as to achieve the goals. It is whether the practice has been well conducted, whether there is any distortion or whether there is any weakness in the practice. 
Assessment is the activity to find whether the determined goals in the planning have been achieved or not. If the goals cannot be achieved; what factors behind it, what problems encountered within the process. The result can be used to revise the future performance. The assessment is not only conducted towards the result or performance, but also towards the educational process. The assessment or evaluation is the final point of an activitiy to know whether it is succeed or not. The result can lead to a better plan.

Management is a form of science, method, arts and profession (Gulick in Satori, 2006). Management is a form of science since it is considered as knowledge which systematically tries to understand why and how human may cooperate. It is a method, since management is based on a specific skill to achieve a managerial achievement and the experts are bound to ethic codes. The specific character of management, however, is the integration and the implementation of knowledge as well as analytical approach developed by many fields of knowledge. It is an art since when functions and the principles of management are put into an act, it may encounter complex problems and it requires a leader with some leadership arts as to achieve the goal effectively and efficiently. It is a profession since it refers to some ethical values of organization requiring specific skills that cannot be conducted by all people (Kurniadin, 2007).

\section{The Teaching and Learning of History}

History as a subject is very important to be understood comprehensively. Since history is a form of knowledge that systematicallyinvestigatesthedevelopment of a society including the past events to be used as guidance in assessing as well as in determining the present and future time wisely.

The Teaching and learning of history as a kind of teaching and learning trying to lead the students to learn or it can be said that it is as a form of an activity to teach students about history (Warsita, 2008). One of the functions of history is to record the experience of the society in the past, which can be used by society in considering the solution towards the problems they encounter (Reiner in Widja, 2002). History involves the knowledge about the past, especially a certain society. The life of society in the past gives some valuable knowledge to the today's society (Soewarso, 1991).

Some advantages in learning history according to Kochhar (2008): (1) developing a self understanding; (2) giving a proper description on the concept of time, space and society; (3) teaching tolerance, either tolerance towards belief, loyalty, culture or ideas; (4) establishing some intellectual attitude;(5) broadening intellectual knowledge; (6) teaching some moral principles;(7) establishing the orientation towards future;(8) giving some mental practice and (9) teaching students to handle controversial issues.

In curriculum 2013, the teaching and learning as one of components is conducted thematically and holistically, integrated with another subjects taught in primary school. In the curriculum of junior high school level, it is conducted integratedly in accordance with the cluster of the subject it belongs to, that is social science. Natural and social sciences are developed as integrative science and integrative social studies, not as a form of 
education on a scientific discipline. It also refers to a form of education that focuses on application, development of thinking development, learning ability, and curiosity, as well as on building awareness and responsibility towards social and natural environment. In curriculum of senior high school level, the history education becomes an independent subject.

The aim of teaching and learning of history is to make students be able to develop their ability in thinking chronologically as well as to have some knowledge about past time that can be used to understand and explain about the process on the development and changes in society as well as the diverstity in social and culture as to find and establish the national character among the world society (Depdiknas, 2004).

The teaching and learning of history in senior high school level has some characteristics as has been explained by some notable historians. One of them is Kuntowijoyo (1995). Badan Standar Nasional Pendidikan (BSNP) or National Standard Board of Education (BSNP, 2006) who states that there are some characteristics of the teaching and learning, namely (1) it studies the problems and development of society from the past to the present time; (2) it has two goals, either for intellectual education or for the education of values, humanity, moral building, character, nationalism and national identity ; (3) it emphasizes more on the critical-logical perspective with socio historical approach.

The characteristics of history education according to Kochhar (2008) are : (1) history studies humankind in the terms of space, humans are studied in the context of physical and geographical environment, either as individual or as a nation ;(2) history explains the present time; (3) history is a dialogue between the past time events and the development towards the future;(4) history refers to stories about the development of the human awareness, either in the individual or collective aspects; (5) continuity and the connectedness are important elements in history.

The development of history curriculum refers to the following principles: (1) the improvement on the belief, noble attitudes, and the internalization on cultural values; (2) the establishment of national integrity may be reached through education that can develop students to feel as a nation through the understanding and respects towards the development of culture and civilization of Indonesia as a nation that can support the world civilization (Depdiknas, 2007).

The core materials of history as a school subject are today's products taken from the existing resources; therefore, the teaching and learning should be more appropriate, critical, independent but apart from a certain party's will. The design of a core material in the teaching and learning can involve the problems in the present time or in the future, mainly those pertaining to life skill, gender equity, human rights, and multicuture. The teaching and learning of history in senior high school levels has two missions: (a) intellectual education and (b) education on values, humanity, moral, character, nationalism, and identity

It can be seen that the curriculum principles as well as the mission of history education in senior high school are in line with the character education designed and started to be effectively practiced in schools. Character education in curriculum 2013 is 
not a separated subject, yet it is integrated in all subjects. Therefore, the teaching and learning can also become a medium to give the character education.

\section{The Importance of Management towards the Teaching and Learning of History}

Human beings basically are God's creature, either as an individual creature or as a social one. Humans cannot live alone without involving others. It is in their capacity as social creature that they gather, socialize in a group of "organization". Organization in a small scale, i.e. family, or the bigger one, like a country, has their own members who have some main goals that are intented to be reached. It is the same with educational organization, especially school as an organization. Their members have the same goals to be reached. To realize the goals, an organization should have a certain programs, plans, or methods, and allocate all resources it has, as well as manage them well, so that the organization can be effectively, efficiently and productively runned.

The teaching and learning should be managed in accordance with the managerial ethics on education so that the goals of the teaching and learning can be effective and efficient. In line with the function of management, William Spiegel (in Kurniadin \& Machali, 2012) states: "Management is that function of an interprise which concers with the direction and control of the various activitiestoattain thebusiness". Management is the function of executive leadership any where. From the statements, it can be clearly seen that management is activities conducted by a leader using all resources as to reach the objective of an organization. Through a good management, it is hoped that the goal can be attained efficiently.

The teaching and learning, basically implements some managerial functions covering: (1) planning; (2) organizing; (3) actuating; (4) controlling or evaluating. It is started with the planning, i.e. the activities of teachers in composing lesson plan. It covers the school identity, the identity of the subject, class, time, standard of competence, basic competence, indicators, objective of the lesson, lesson materials, methods, activities, sources and teaching media as well as evaluation. This step is actually the practice of the managerial function of planning.

After determining the lesson plan, the next step is teaching and learning process. In this process, teachers act as a leader, facilitator, mediator, motivator and evaluator. It is within the process that the coordination, cooperation, and communication as the core of management are implementated as to achieve the goals of the teaching and learning of history. In this process, teachers should organize and manage the scope of teaching and learning management. The details are as in the following table.

Educational Management Scope

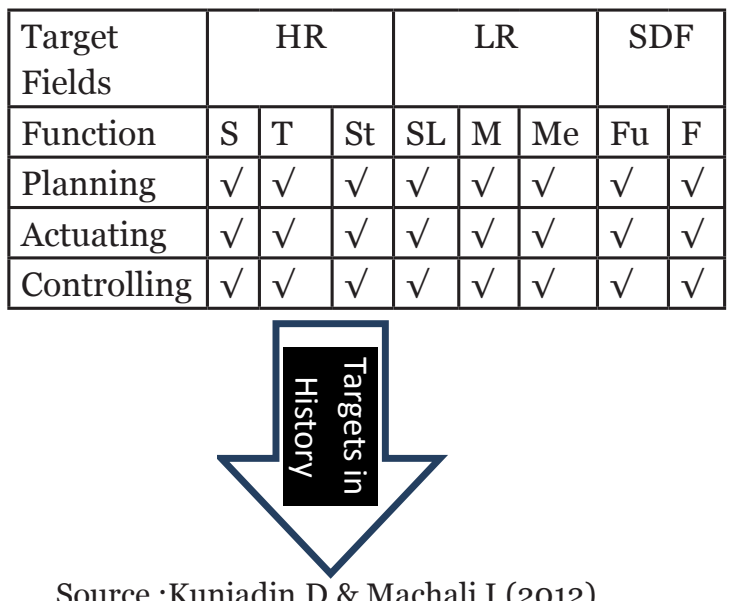

Source :Kuniadin,D.\& Machali I.(2012) 
Note

$\mathrm{S}$ : Students

$\mathrm{T}$ : Teacher

St : Stockholders

SL : Sillabus

HR : Human Resource

LR : $\quad$ Learning Resource

M : Teaching Method

Me : Media

$\mathrm{Fu}$ : Fund

F : Facility

SDF: facility and finance

TE : Targets of Education

Teaching and learning process implements coordination, cooperation and communication as the core of management as well as other abilities. Teachers in the process should have some basic skills in teaching. The basic skills in teaching should be mastered by teachers in the teaching and learning of history are the skills to open and close the lesson, to explain, to ask and to give some feedback and some rehearsal, to make some variasion, to lead a small discussion within a group and individual as well as to manage the class (UPPL Team, 2012).

In the process, it implements actuating and controlling. Actuating has a function in realizing the result of planning and organizing. Actuating or directing man power in the teaching and learning of history refers to the acts of directing and empowering the potentials in teaching and learning namely the students as well as the media needed in the history teaching. The sources in the context of educational management are as follows (1) man, including teachers, students and staffs; (2) money; (3) materials; (4) methods;
(5) market ; and (6) minutes. Actuating in teaching is an effort as to encourage students to reach the objective of the teaching learning (Rohman \& Amri, 2012), (Kurniadin \& Machali, 2012).

The assessment in teaching and learning of history known as evaluation is an activity to find whether the objective of the teaching can be reached or not. The evaluation of teaching and learning is conducted at the end of the process and teaching. The evaluation not only covers the cognitive aspect, but also affective and psychomotor. Teaching and learning is in line with its goal, namely to build characters based on Pancasila.

\section{Conclusion}

The practice of curriculum 2013 is one of the efforts in building the national character. The character building is as an answer towards the condition and situation of education in Indonesia lately. The education as well as the teaching and learning of history is aimed at fostering students' ability, namely to make them to be able to develop chronological thinking and to have knowledge about past time to be used in understanding the development and changes in society as well as cultural diversity as to establish the national identity among the world society.

To achieve the goal, it requires some concrete steps, i.e to havely an effective, efficient and productive teaching and learning. Therefore, in the education as well as the teaching and learning of history there should be education management, especially which covers management functions of planning, organizing, actuating and controlling. In the educational field, including in the teaching and learning of history, there is a 
need towards management, and in a certain part, the management can be implemented to have an optimum result. The expected result of education management towards the teaching and learning is productivity. Productivity in the education as well as the teaching and learning is reflected in the effectivity and efficiency[]

\section{REFERENCES}

BSNP. (2006). Petunjuk Tehnis Pengembangan Silabus dan Contoh/ Model SilabusSMA/MA Mata Pelajaran Sejarah. Jakarta: Departemen Pendidikan Nasional.

Depdiknas. (2004). Kurikulum dan Hasil Belajar Kompetensi Dasar Mata Pelajaran Pengetahuan Sosial SMP dan MTs. Jakarta: Pusat Kurikulum Balitbang Depdiknas.

Departemen Pendidikan Nasional, KTSP. (2006). Standar Kompetensi Mata Pelajaraan IPS. Jakarta: Depdiknas.

Departemen Pendidikan Nasional. (2007).

Pertunjuk Tehnis Pengenbangan

Silabus dan Contoh/ Model Silabus Mata Pelajaran Sejarah. Jakarta: Depdiknas.

Engkoswara \& Aan Komariah. (2010). Administrasi Pendidikan. Bandung: Alfabeta.

Hasan, S.H. (1996). Pendidikan Ilmu Sosial. Jakarta: Dirjendikti, Depdikbud Republik Indonesia.

Hasbullah. (2006). Manajemen Sumber Daya Manusia. Jakarta: Rinekacipta, Made,P.M.(2004).ManajemenPendidikan CRT II . Jakarta: Rinekacipta.
Isjoni. (2007). Pembelajaran Sejarah pada Satuan Pendidikan. Alfabeta: Bandung.

Kochhar, S. (2008). Teaching of History. Jakarta: Grasindo.

Kuntawijaya. (1995). Pengantar Ilmu Sejarah. Yogyakarta: Bentang.

Kurniadin \& Machali. (2012). Manajemen Pendidikan Konsep dan Prinsip Pengelolaan Pendidikan. Yogyakarta: Ar- Ruzz Media.

Lee, P.J. (1984). Learning History. Liverpool (Britain): Heineman Educational Book

Koonz. (1980). Management Function and Strategy. Tokyo: P Mc. Graw Hill Kogakusha.

Mulyana D. (2010). Ilmu Komunikasi, Suatu Pengantar. Bandung: PT Remaja Rosdakarya.

Naim, N. (2011). Dasar-Dasar Komunikasi Pendidikan. Yogyakarta: Ar- Ruszz Media.

Rohman M. \& Amri S. (2012). Manajemen Pendidikan. Analisis dan Solusi Terhadap Kinerja Manajemen Kelas dan Strategi pengajaran Yang Efektif Yogyakarta: Ar- Ruszz Media.

Sharma, S.K. (2008). Teaching of History. New Delhi: Lotus Press

Terry, G. R. (1960). The Principles of Management, Third Edition. Homewood Illinois : Richard Irwm.

Tilaar, H.A.R. (2006). Manajemen Pendidikan Nasional. Bandung: Rinekacipta,

Tilaar, H.A.R. (2006). Beberapa Agenda Reformasi Pendidikan Nasional 
(dalam Perspektif abad 21). Magelang: Widya, I. G. (2002). Menuju Wajah Baru Tera Indonesia.

Pendidikan Sejarah. Yogyakarta:

Tim UPPL. (2012). Handout Pengajaran Lappera Pustaka Umum.

Mikro Untuk Mahasiswa FKIP Warsita.(2008).TekhnologiPembelajaran. Universitas Jember. Jember: UPPL Jakarta: Rinekacipta.

Pengajaran Mikro Teaching Universitas Wiriaatmadja, R. (2003). Pendidikan Jember,

Sejarah di Indonesia Perspektif Lokal,

UUSPN. Nomor 20 Tahun 2003 and UUSPN Nomor 2 Tahun 1989. Nasional, dan Global. Bandung: Historia Utama Press

Universitas Jember, (2011). Pedoman Penulisan Karya Ilmiah. Jember: Jember University Press.

Williams, R, (1983). Keyword, London: Fontana. 